\title{
Interrogate Indonesian EFL Learners' Needs on Academic Writing Instruction
}

\author{
Mohammad Rudiyanto, Dayat
}

\begin{abstract}
The present study aims to address the graduate students' needs on instructional and assessment practices for preparing curriculum of Teachers' Training College in Indonesian EFL context. 184 first-year students, who are currently completing their basic writing course at first semester. Survey research was employed to gather the empirical data which covered needs analysis through Google Docs. The data were, then, analysed using frequencies of descriptive statistics in SPSS22 version. The findings revealed that writing teacher pay particular attention on designing the curriculum since students interest are divergent, including writing text selection, course credit, determination of teaching method, the manner of written corrective feedback, revision, and assessment. The contribution of the study is to provide basic data of student needs in academic writing instruction for developing curriculum especially in EFL Indonesian context.
\end{abstract}

Index Terms:- Academic writing, curriculum development, EFL, needs analysis.

\section{INTRODUCTION}

In recent years, there have been studies on needs analysis of writing for academic purpose [1], publication of international journals [2], but in Indonesian EFL context, very few have investigated EFL writing for teacher education. This study reports needs analysis of students of teacher education for preparing writing curriculum since writing skill recently becomes the centre of teaching and learning fulfilling a range of purposes according to academic curriculum.

Academic curriculum especially writing, is commonly designed based on the goal of program which is explicitly written in syllabus. Concerning with the goal of writing instruction, views that the primary goal of writing instruction is 'to provide students with the knowledge to become effective users of written English3. It means the goal is not just to provide simple formulas and rules for 'correct' English (although they are also important) but students are expected to be competent, confident and articulate English users [3].

In Indonesian EFL context, the writing quality of most students is still weak [4] since writing is viewed as complicated task [5], [6]. Although the learners master the writing process, they may still have a product that is difficult for native English speakers and their instructors to understand [7].

However, writing requires not only knowledge of generating reasonable and obvious ideas, good grammatical structure and feasible content, demonstrating accurate language expressions, but it also takes social interaction in

Mohammad Rudiyanto, Madura University, Jl. Panglegur Km 3,5 Pamekasan Jawatimur, Indonesia

Dayat, Yogyakarta State University, Jl. Colombo No. 1 Yogykarta, Indonesia.
Revised Manuscript Received on July 10, 2019.

which the relationship between a writer and readers is socially situated [5], [8], [9]. To achieve these abilities, teaching writing should reflect to independent thinking skills which embody ability to classify, evaluate, and synthesize [10].

In addition, when being traditionally assessed, students often meet frustrations (feeling annoyed) when they are required to undergo regular assessment to show mastery of competence to pass to the next level of instruction [11]. Such traditional assessment inclines to scores on static instruments as indication of actual level of performance (or known as zone of actual development/ZAD) which reflects past learning activity [12]. The measures can underrate the abilities and potential of students (or zone of proximal development/ZPD), in particular, those from minority groupings, disadvantaged socioeconomic contexts, or those with linguistic difficulties. Therefore, it is required to unite assessment and instruction to identify what students are lacking and develop their language repertoire by providing the students with sufficient teacher scaffolding and peer support [13].

To solve this, it is required to accumulate the learners' needs on instructional practices of academic writing including teaching writing, corrective feedback method and assessment. Thus, needs analysis or needs assessment have been conducted. Needs analysis is 'used to refer to the techniques for collecting and assessing this kind of information: the means of establishing the how and what of a course [14]. Needs analysis is a shade of preparing 'lesson planning, syllabus design, materials evaluation and development, and instructional design and assessment development [15]. This recent study aims to address the graduate students' needs on instructional and assessment practices for preparing curriculum of Teachers' Training and Education College in Indonesian EFL context.

\section{MATERIALS AND METHODS}

This is the standard font and layout for the individual paragraphs. The style is called "Paragraph." Replace this text with your text. The "Enter" key will take you to a new paragraph. If you need to insert a hard line break within the paragraph. This is the paragraph spacing that occurs when you use the Enter key. To ensure validity and reliability of the results, the instrument embraced literature reviews and

ELT expert judgement. Reviewing relevant literatures was used to construct the instruments related to the problem of this study. An associate professor who had been experienced 
in ELT and needs analysis adjusted all question items. Several questions were adopted from [16]. It was due to the relevance of the recent study which teaching writing evaluation and instructive feedback in writing class.

To collect data, the researcher utilized Google Docs in order to implement the survey. The result of survey data was then automatically saved into a Google Sheets spreadsheet, where the researcher enables put the data to work [17]. The participants accessed easily the survey through laptop with Wi-Fi connection provided by the campus. The participants were asked to answer some close-ended questions and they also had opportunity to utilize their own responses if the answers provided need to add. The data collected from the needs analysis questionnaires was then used as consideration of designing the curriculum. After the data collected and analyzed, the results were compiled and examined in the findings and discussion section.

This recent study used descriptive methods to address the graduate students' needs for effective academic writing instruction. It was preliminary study conducted to design curriculum for academic writing instruction. Survey research was employed to gather the empirical data which covered needs analysis which will then be used to design 'lesson planning, syllabus design, materials evaluation and development, and instructional design and assessment development [13].

\section{A. Participants}

A total of 184 first-year EFL students participated in this study. They were currently completing their basic writing course at first semester of the first year. These participants were main respondents from whom information required to address the purpose of this study. Two weeks before the needs analysis questionnaires spread out, the researcher cooperated with two basic writing lecturers to inform their students to take part in the research occasion, and to determine the time and place. This was conducted to avoid disturbing teaching learning process. Furthermore, the students were asked to bring their own laptop or mobile phone due to filling the questionnaire in online. The reason for selecting the respondents was that to prepare better curriculum for next semester (second semester).

\section{B. Procedures}

One month before conducting the research, the researcher asked the Head of English Study Programme for permission and pointed the lecturers to help the researcher collecting the data. After two basic writing lecturers had been determined to be volunteers, then the researcher discussed how the survey could be applied during the class. The discussion was carried out by phone and WhatsApp via due to the researcher is currently studying doctoral programme in Jogjakarta while the research setting was in Pontianak, West Borneo (Kalimantan Barat). The discussion included the needs analysis questionnaires which had been sent to their email two weeks before implementing the research as well as the procedure of filling the forms. The discussions with two volunteers were conducted interchangeably. After they understood all the questions provided in the questionnaire and what to, then the researcher gave the link to access Google Docs. We determined not only the appropriate time to carry out a questionnaire but also WI-FI connection at campus. In addition, the roles of volunteers here were as a supervisor during the process of filling the questionnaire done in the classroom. Their job was also to give the students instructions how to fill in the questionnaire. In addition, the volunteers helped students when they found difficulty in answering the questions.

To fill the needs analysis questionnaires, the students were recommended by the lecturers to use laptop one week before conducting survey since it was easier to access, and to read and answer the questions. Before implementing the survey, the lecturers gave link of Google Docs (URL) to access and answer the questions. During the activities, the students had opportunity to ask when they found difficulty to answer the questions. At the end of the survey, the lecturers asked the students to re-check whether all the questions had been answered.

After the survey had been carried out, the researcher saved the participant responses in the spreadsheet provided by Google Docs to avoid to data corruption or data loss from the networks. Furthermore, the data were converted into Microsoft Excels due to the result of Google Docs analysis sometimes was need to be corrected. Thus, SPSS22 version was also employed to produce more accurate result Data Analysis.

The analysis of the survey data involved a series of procedures. The structure of the survey itself contributed in coding efficiency. The answers of the questions ranged from 0-4 and 1-4. Zero indicated no importance or not all useful/need and 4 specified essential importance (for instance very useful or more than I need). While, 1 meant not important or not at all useful/need (in this study used not at all) and 4 indicated most important or very useful. The survey data were exported from the online collector, Google Doc, into Excel document. The compiled spreadsheet was analyzed using descriptive statistic (this was conducted to see the frequencies of the students' needs in terms of academic writing instruction) through SPSS 22 version. It was due to make decision, the most common answers were undertaken. Descriptive statistics was used to analyze the survey data. All student responses were calculated, and then analyzed to determine frequency of the needs.

\section{RESULTS AND ANALYSIS}

\section{A. Demographic Information of the Survey Participants}

This study examined the undergraduate students' needs on instructional and assessment practices for preparing curriculum of Teachers' Training College in Indonesian EFL context including writing materials, instruction and assessment. To begin, the data of participant background were analyzed to provide further definition of the study population. The statistical analysis was carried out to collect the demographic data provided by the survey participants including gender, native language, learning English

experience, writing ability, and future profession. Demographic details are presented in Table 1. This 
information can be used for preparing curriculum in EFL academic writing context.

Table 1: The percentage of the demographic information of the survey participants

\begin{tabular}{|c|c|c|c|}
\hline Item & Range/Coding & Frequency & Percentage \\
\hline Gender & 1= Male & 51 & $27.7 \%$ \\
\cline { 2 - 4 } & 2= Female & 133 & $72.3 \%$ \\
\hline \multirow{4}{*}{$\begin{array}{c}\text { Native } \\
\text { language }\end{array}$} & $\begin{array}{c}\text { 1= Bahasa } \\
\text { Indonesia }\end{array}$ & 177 & $96.2 \%$ \\
\cline { 2 - 4 } & 2= Malay & 4 & $2.2 \%$ \\
\cline { 2 - 4 } & 3= Dayakness & 1 & $0.5 \%$ \\
\cline { 2 - 4 } & 4= Javaness & 2 & $1.1 \%$ \\
\hline \multirow{4}{*}{$\begin{array}{c}\text { Writing } \\
\text { Ability }\end{array}$} & 1= Low & 33 & $17.9 \%$ \\
\cline { 2 - 4 } & 2= Fair & 96 & $52.2 \%$ \\
\cline { 2 - 4 } & 3= Good & 51 & $27.7 \%$ \\
\cline { 2 - 4 } & 4= Excellent & 4 & $2.2 \%$ \\
\hline
\end{tabular}

Interestingly, not all teacher training students wanted to be teachers, but they have another desire outside their current study. It is however challenging for those who aspire beyond being a teacher since they have to struggle again to fulfil other skills they need.

\section{Frequency of Academic Writing Texts}

To concern academic writing instruction, the results of descriptive analysis start from how frequent the students write the texts. This information is used to determine texts/genres to be taught in academic writing course. Table 2 indicates that students' writing interest is still categorized as low recently. It can be seen from column more often, the average percentage shows only $9.2 \%$ students who are interested in writing text. Similarly, at column never (25.9\%) and seldom (40.1\%) occupy high position. It can be inferred that student writing habit is low.

Table 2: The frequency of students writing texts

\begin{tabular}{|l|c|c|c|c|}
\hline \multicolumn{1}{|c|}{ Kinds of Texts } & \multicolumn{4}{c|}{ Frequency (\%) } \\
\hline & Never & Seldom & Often & $\begin{array}{c}\text { More } \\
\text { Often }\end{array}$ \\
\hline $\begin{array}{l}\text { Information writing } \\
\text { assignment }\end{array}$ & 5.4 & 35.9 & 44.0 & 17.7 \\
\hline Extended assignment & 27.2 & 32.1 & 34.2 & 6.5 \\
\hline Case study & 27.2 & 32.1 & 34.2 & 6.5 \\
\hline Review & 13.6 & 37.0 & 37.0 & 12.5 \\
\hline Technical report & 27.7 & 42.9 & 20.1 & 9.1 \\
\hline Lab report & 39.7 & 35.9 & 16.8 & 7.6 \\
\hline Book report & 22.3 & 33.2 & 31.0 & 13.6 \\
\hline $\begin{array}{l}\text { Critical } \\
\text { analysis/critique }\end{array}$ & 20.1 & 46.7 & 22.3 & 10.9 \\
\hline Bibliography & 40.2 & 37.5 & 17.4 & 4.9 \\
\hline $\begin{array}{l}\text { Annotated } \\
\text { bibliography }\end{array}$ & 41.3 & 39.7 & 12.5 & 6.5 \\
\hline Literature review & 30.4 & 41.3 & 19.6 & 8.7 \\
\hline Term paper & 19.0 & 45.1 & 26.1 & 9.8 \\
\hline $\begin{array}{l}\text { Research paper: } \\
\text { 1) Short }\end{array}$ & 22.3 & 41.3 & 30.4 & 6.0 \\
2) Argumentative & & & & \\
\hline $\begin{array}{l}\text { Position/opinion } \\
\text { paper }\end{array}$ & 22.3 & 44.0 & 25.5 & 8.2 \\
\hline & & & & \\
\hline
\end{tabular}

\begin{tabular}{|c|c|c|c|c|}
\hline $\begin{array}{l}\text { Essay: } \\
\text { 1) Definitional } \\
\text { essay } \\
\text { 2) Expository }\end{array}$ & 26.1 & 36.4 & 29.9 & 7.6 \\
\hline Subject outline & 27.7 & 45.1 & 20.7 & 6.5 \\
\hline Statistical summary & 32.1 & 48.9 & 13.6 & 5.4 \\
\hline Senior thesis & 43.5 & 31.0 & 18.5 & 7.1 \\
\hline Grant writing & 30.4 & 40.2 & 21.7 & 7.6 \\
\hline E-mail & 22.3 & 46.7 & 17.4 & 13.6 \\
\hline Web writing & 38.0 & 33.7 & 17.9 & 10.3 \\
\hline $\begin{array}{l}\text { Oral presentation of } \\
\text { written report }\end{array}$ & 18.5 & 35.9 & 31.0 & 14.7 \\
\hline $\begin{array}{l}\text { PowerPoint } \\
\text { presentation }\end{array}$ & 20.7 & 33.7 & 33.2 & 12.5 \\
\hline $\begin{array}{l}\text { Historical research } \\
\text { (primary } \\
\text { secondary sources) }\end{array}$ & 24.5 & 52.2 & 15.2 & 8.2 \\
\hline $\begin{array}{l}\text { Midterm/final exam } \\
\text { essay }\end{array}$ & 15.2 & 41.3 & 35.9 & 7.6 \\
\hline $\begin{array}{l}\text { Resume and other } \\
\text { 'business' writing }\end{array}$ & 24.5 & 41.8 & 27.2 & 6.5 \\
\hline $\begin{array}{l}\text { Experiential } \\
\text { Learning-related } \\
\text { project/assignment }\end{array}$ & 18.5 & 48.9 & 25.0 & 7.6 \\
\hline $\begin{array}{l}\text { Service Learning- } \\
\text { related } \\
\text { project/assignment }\end{array}$ & 29.3 & 37.0 & 24.5 & 9.2 \\
\hline $\begin{array}{l}\text { Independent } \\
\text { study/Lifelong } \\
\text { learning-related } \\
\text { activity }\end{array}$ & 20.1 & 44.0 & 23.4 & 12.5 \\
\hline Average & 25.9 & 40.1 & 25.0 & 9.2 \\
\hline
\end{tabular}

Notes: These categories were adopted from Reference/Instruction Department of Indiana State University Library, 2004.

\section{Credits Requirement in Academic Writing Course}

To emerge the needs on academic writing course credit, the students had difference demands on it. Based on the result of survey, Table 3 summarizes that requirements of the academic writing course was that most students wished it could be accomplished in two credits (63.0\%). This indicates that most students are not interested in academic writing course.

Table 3: The credits requirement in academic writing course

\begin{tabular}{|c|c|c|}
\hline Course Credit & Frequency & Percent \\
\hline Two credits & 116 & $63.0 \%$ \\
\hline Three credits & 31 & $16.8 \%$ \\
\hline Four credits & 37 & $20.1 \%$ \\
\hline
\end{tabular}

D. Students' Experience on Writing Process

Writing can be viewed as a process including planning, drafting, and revising. In summary of process of writing

Published By: 
(planning, drafting, revising), the following table presents the learning experience during this semester (the students are recently in the first semester). Another finding on student experiences on the writing process is provided in Table 4. This result showed that learners' response on writing process or procedures experience in the writing course are destitute in practice.

Table 4: Students' responses on writing process

\begin{tabular}{|c|c|c|}
\hline $\begin{array}{c}\text { The Students' Responses on } \\
\text { Learning Experience }\end{array}$ & Frequency & Percentage \\
\hline 1= Not at all & 18 & $9.8 \%$ \\
\hline 2= Just once & 49 & $26.6 \%$ \\
\hline 3= Sometimes & 69 & $37.5 \%$ \\
\hline 4= Often & 33 & $17.9 \%$ \\
\hline 5= Almost always & & \\
\hline
\end{tabular}

\section{E. Students' Perception on Needs of Writing Process}

Table 5 reflects the learning experience of writing process, this finding indicates that writing process is important for students to write better.

Table 5: Students' perception on needs of writing process

\begin{tabular}{|c|c|c|}
\hline $\begin{array}{c}\text { The Students' Responses on } \\
\text { Writing Process (Planning, } \\
\text { Drafting, Revising) }\end{array}$ & Frequency & Percent \\
\hline 1= Not at all or very little & 20 & $10.9 \%$ \\
\hline 2= Yes, somewhat & 33 & $17.9 \%$ \\
\hline 3= Yes, fairly & 83 & $45.1 \%$ \\
\hline 4= Yes, very much & 48 & $26.1 \%$ \\
\hline
\end{tabular}

\section{F. Students' Perception on the Benefit of Writing Process}

Writing process has major impact to writing teaching. The following table displays the students' perception on the benefit of writing process. This finding indicates that planning was more important for the students than other activities (Table 6).

Table 6: Students' perception on the benefit of writing process

\begin{tabular}{|c|c|c|c|c|}
\hline \multirow{2}{*}{$\begin{array}{c}\text { Writing } \\
\text { Process }\end{array}$} & \multicolumn{4}{|c|}{ Frequency of Responses } \\
\cline { 2 - 5 } & $\begin{array}{c}\text { Not At } \\
\text { All Useful }\end{array}$ & $\begin{array}{c}\text { Somewhat } \\
\text { Useful }\end{array}$ & $\begin{array}{c}\text { Fairly } \\
\text { Useful }\end{array}$ & $\begin{array}{c}\text { Very } \\
\text { Useful }\end{array}$ \\
\hline Planning & $5.4 \%$ & $24.5 \%$ & $37.5 \%$ & $33.2 \%$ \\
\hline Drafting & $9.2 \%$ & $32.1 \%$ & $29.3 \%$ & $29.3 \%$ \\
\hline Revising & $14.7 \%$ & $23.9 \%$ & $29.3 \%$ & $32.1 \%$ \\
\hline
\end{tabular}

\section{G. Students' Needs on Writing Lesson}

These are writing resources and activities the students had received in writing classes, including writing lesson (grammar knowledge, composition lesson (how to organize essay, vocabulary and expression, text structure), learning materials (these refer to the learning sources), and writing instruction. These emerge the evaluation how useful they are. Composition lesson has the highest position for fairly useful category in writing lesson. In very useful category, students had more frequency to learn vocabulary and expression. It does not mean that neglect other lessons, grammar knowledge and text structure were also fairly useful for them. Table 7 shows the survey results of the students' responses on writing lesson

Table 7: Students' experience on writing lesson

\begin{tabular}{|c|c|c|c|c|}
\hline \multirow{2}{*}{ Writing Lesson } & \multicolumn{5}{|c|}{ Frequency of Responses } \\
\cline { 2 - 5 } & Not At All Useful & Somewhat Useful & Fairly Useful & Very Useful \\
\hline Grammar knowledge & $4.9 \%$ & $32.6 \%$ & $33.7 \%$ & $28.8 \%$ \\
\hline Composition lesson (how to organize essay) & $7.6 \%$ & $30.4 \%$ & $39.1 \%$ & $22.8 \%$ \\
\hline Vocabulary and Expression & $2.7 \%$ & $26.6 \%$ & $38.0 \%$ & $32.6 \%$ \\
\hline Text Structure & $4.9 \%$ & $31.5 \%$ & $33.7 \%$ & $29.9 \%$ \\
\hline
\end{tabular}

\section{H. Students' Requirement on Learning Materials}

Regarding to learning materials, textbook was dominantly used by most students. The second material was writing module. For more detail, Table 8 shows students' requirement on learning materials.

Table 8: The students' requirement on learning materials

\begin{tabular}{|c|c|c|c|c|}
\hline \multirow{2}{*}{ Materials } & \multicolumn{4}{|c|}{ Frequency of Responses } \\
\cline { 2 - 5 } & $\begin{array}{c}\text { Not At } \\
\text { All Useful }\end{array}$ & $\begin{array}{c}\text { Somewhat } \\
\text { Useful }\end{array}$ & $\begin{array}{c}\text { Fairly } \\
\text { Useful }\end{array}$ & $\begin{array}{c}\text { Very } \\
\text { Useful }\end{array}$ \\
\hline Textbook & $5.4 \%$ & $22.4 \%$ & $45.7 \%$ & $26.6 \%$ \\
\hline e-book & $23.9 \%$ & $36.4 \%$ & $25.0 \%$ & $14.7 \%$ \\
\hline $\begin{array}{c}\text { Writing } \\
\text { module }\end{array}$ & $13.0 \%$ & $40.8 \%$ & $30.4 \%$ & $15.8 \%$ \\
\hline Dictionary & - & - & $0.5 \%$ & - \\
\hline Diary & - & - & $0.5 \%$ & - \\
\hline
\end{tabular}

\section{Students' Requirement on Writing Instruction}

The teaching writing, the students were asked to indicate writing instruction during the class, most students need to involve more frequently to writing activity in the classroom ( $42.4 \%$, for fair category), and second position fair category is that the students need some examples of texts before writing task given (37.5\%) [16]. For very useful category, most students (26.6\%) need some examples of texts before writing task given, the second one is that the students need to involve more frequently to writing activity in the classroom (25.5\%). The students still need teacher's assistance while coping with writing task in the classroom (24.5\%). Furthermore, additional time in writing activity $(1.6 \%)$ and dictionary are still required during the class $(1.6 \%)$. Table 9 provides the detail information.

Sciences Publication 
Table 9: The students' requirement on writing instruction

\begin{tabular}{|c|c|c|c|c|}
\hline \multirow{2}{*}{ Writing Instruction } & \multicolumn{3}{|c|}{ Frequency of Responses } \\
\cline { 2 - 5 } & $\begin{array}{c}\text { Not At } \\
\text { All Useful }\end{array}$ & $\begin{array}{c}\text { Somewhat } \\
\text { Useful }\end{array}$ & $\begin{array}{c}\text { Fairly } \\
\text { Useful }\end{array}$ & $\begin{array}{c}\text { Very } \\
\text { Useful }\end{array}$ \\
\hline I need some examples of texts before writing task given & $4.9 \%$ & $31.0 \%$ & $37.5 \%$ & $26.6 \%$ \\
\hline I need to involve more frequently to writing activity in the classroom & $6.0 \%$ & $26.1 \%$ & $42.4 \%$ & $25.5 \%$ \\
\hline I need a lecturer's assistance while I am writing in the classroom & $17.4 \%$ & $29.9 \%$ & $28.3 \%$ & $24.5 \%$ \\
\hline I need more time in writing activity & - & - & - & $1.6 \%$ \\
\hline I need dictionary during writing activity & - & - & - & $1.6 \%$ \\
\hline
\end{tabular}

\section{J. Students' Requirement on Writing Practice}

Writing process involves several activities, planning, drafting, and revising. To have good writing, students need to writing practice. The table below shows writing practice in form percentage. From Table 10, it can be concluded that practice is the highest demand for fairly useful category $(42.9 \%)$, the second position is drafting $(38.0 \%)$, and followed by revising practice as the third position $(37.5 \%)$. In contrast, in very useful category is revising practice is the highest position the students need $(22.8 \%)$.
Table 10: The students' requirement on writing practice

\begin{tabular}{|c|c|c|c|c|}
\hline \multirow{2}{*}{$\begin{array}{c}\text { Writing } \\
\text { Practice }\end{array}$} & \multicolumn{4}{|c|}{ Frequency of Responses } \\
\cline { 2 - 5 } & $\begin{array}{c}\text { Not At Useful } \\
\text { Useful }\end{array}$ & $\begin{array}{c}\text { Somewhat } \\
\text { Useful }\end{array}$ & $\begin{array}{c}\text { Very } \\
\text { Useful }\end{array}$ \\
\hline $\begin{array}{c}\text { Planning } \\
\text { Practice }\end{array}$ & $7.6 \%$ & $28.8 \%$ & $42.9 \%$ & $20.7 \%$ \\
\hline $\begin{array}{c}\text { Drafting } \\
\text { Practice }\end{array}$ & $11.4 \%$ & $31.5 \%$ & $38.0 \%$ & $19.0 \%$ \\
\hline $\begin{array}{c}\text { Revising } \\
\text { Practice }\end{array}$ & $13.6 \%$ & $26.1 \%$ & $37.5 \%$ & $22.8 \%$ \\
\hline
\end{tabular}

\section{K. Students' Need on Types of Corrective Feedback}

The choice which errors should be corrected, the student needed idea, topics, and content to be more corrected but it does not mean the teacher ignore other aspects for instance grammar, style, and so on. Table 11 shows the detail information.

Table 11: The students' requirement on types of corrective feedback

\begin{tabular}{|c|c|c|c|c|}
\hline \multirow[t]{2}{*}{ Writing Instructor's Feedback } & \multicolumn{4}{|c|}{ Frequency of Responses } \\
\hline & $\begin{array}{c}\text { Not At } \\
\text { All Useful }\end{array}$ & $\begin{array}{c}\text { Somewhat } \\
\text { Useful }\end{array}$ & $\begin{array}{l}\text { Fairly } \\
\text { Useful }\end{array}$ & $\begin{array}{c}\text { Very } \\
\text { Useful }\end{array}$ \\
\hline Feedback on grammar, style, and other linguistic errors & $12.0 \%$ & $38.6 \%$ & $27.2 \%$ & $22.3 \%$ \\
\hline Feedback on structure and organization of essay & $9.2 \%$ & $36.4 \%$ & $35.9 \%$ & $18.5 \%$ \\
\hline Feedback on idea, topics, and content & $11.4 \%$ & $27.7 \%$ & $37.5 \%$ & $23.4 \%$ \\
\hline
\end{tabular}

\section{Amount of Revision Need}

Revising stage is important stage after the students receive corrective feedback $(\mathrm{CF})$ in the meeting. Results of revising activity presented in accordance with how many times the students need to revise for their work. The following table provides the detail of the need of revision (Table 12).

\section{Student Reasons for Revision}

Related to response to revision, Table 13 shows students' reason they were willing to revise their work. Interestingly, the information from Table 13 shows most students say that revise their writing for practice since it will be useful to improve their quality of their writing skills. This is important findings for consideration in teaching writing.

Table 12: The result of statistical analysis for survey question on the amount of revision need

\begin{tabular}{|c|c|}
\hline $\begin{array}{c}\text { The Amount of Revision } \\
\text { Need }\end{array}$ & Frequency of Responses \\
\hline Never & $9.8 \%$ \\
\hline One time & $16.8 \%$ \\
\hline Twice & $32.6 \%$ \\
\hline 3-4 times & $25.0 \%$ \\
\hline More than 4 times & $15.8 \%$ \\
\hline
\end{tabular}


Table 13: The reasons for revision

\begin{tabular}{|c|c|c|c|c|}
\hline \multirow[b]{2}{*}{ The Students' Reasons } & \multicolumn{4}{|c|}{ Frequency of Responses } \\
\hline & $\begin{array}{l}\text { Strongly } \\
\text { Disagree }\end{array}$ & $\begin{array}{l}\text { Somewhat } \\
\text { Disagree }\end{array}$ & $\begin{array}{l}\text { Somewhat } \\
\text { Agree }\end{array}$ & $\begin{array}{l}\text { Strongly } \\
\text { Agree }\end{array}$ \\
\hline I revise my writing to fulfill the requirement. It is required to revise. & $8.7 \%$ & $32.6 \%$ & $46.7 \%$ & $12.0 \%$ \\
\hline $\begin{array}{l}\text { I revise my writing to get higher grade on this essay because I want } \\
\text { higher scores for my final grading. }\end{array}$ & $7.1 \%$ & $33.9 \%$ & $30.6 \%$ & $28.4 \%$ \\
\hline $\begin{array}{l}\text { I revise my writing for practice. I think that revision will be useful to } \\
\text { improve my writing skills. }\end{array}$ & $7.6 \%$ & $26.6 \%$ & $31.0 \%$ & $34.8 \%$ \\
\hline $\begin{array}{l}\text { I revise my writing to improve the quality of the essay. I want to } \\
\text { improve the quality of the essay to satisfy myself. }\end{array}$ & $7.7 \%$ & $23.0 \%$ & $38.8 \%$ & $30.6 \%$ \\
\hline
\end{tabular}

\section{N. Students' Preference on Type of Feedback}

Related to types of corrective feedback, the students of teacher training and education have different preference on them (Table 14). Table 14 shows that dialogic feedback the most students expected although direct $\mathrm{CF}$ is also important as well. However, both dialogic and direct feedback can be applied in providing feedback to student writing.

Table 14: The students' preference on type of feedback

\begin{tabular}{|c|c|c|c|c|}
\hline \multirow{2}{*}{ Writing Instructor's Feedback } & \multicolumn{3}{|c|}{ Frequency of Responses } \\
\cline { 2 - 4 } & No At All Useful & Somewhat Useful & Fairly Useful & Very Useful \\
\hline Correction with solution (direct CF) & $7.6 \%$ & $29.9 \%$ & $33.2 \%$ & $29.3 \%$ \\
\hline Correction without solution (indirect CF) & $22.3 \%$ & $35.3 \%$ & $28.8 \%$ & $13.6 \%$ \\
\hline Using error codes on wrong words/phrases/clauses & $14.7 \%$ & $37.5 \%$ & $28.3 \%$ & $19.6 \%$ \\
\hline $\begin{array}{c}\text { Using Explanation on wrong } \\
\text { words/phrases/clauses }\end{array}$ & $8.2 \%$ & $33.2 \%$ & $34.2 \%$ & $24.5 \%$ \\
\hline Focused CF (correction on grammar only) & $10.9 \%$ & $37.5 \%$ & $32.1 \%$ & $19.6 \%$ \\
\hline Unfocused CF (all writing aspects) & $18.1 \%$ & $41.2 \%$ & $26.0 \%$ & $14.7 \%$ \\
\hline Dialogic Feedback & $14.8 \%$ & $28.4 \%$ & $36.1 \%$ & $20.8 \%$ \\
\hline
\end{tabular}

O. Students' Responses on Corrective Feedback

The responses on corrective feedback, Table 15 provides student experience when they got corrective feedback from their writing teacher in the first year.

Table 15: The students' responses on corrective feedback

\begin{tabular}{|c|c|c|c|c|c|}
\hline \multirow[b]{2}{*}{$\begin{array}{l}\text { The Students' } \\
\text { Responses }\end{array}$} & \multicolumn{5}{|c|}{ Frequency of Responses } \\
\hline & $\begin{array}{l}\text { I do not } \\
\text { get } \\
\text { feedback } \\
\text { on this }\end{array}$ & $\begin{array}{l}\text { I do } \\
\text { not } \\
\text { read it }\end{array}$ & $\begin{array}{l}\text { I read it, } \\
\text { but I } \\
\text { ignore it }\end{array}$ & $\begin{array}{l}\text { I read it and try to use } \\
\text { some of suggestions } \\
\text { to improve my } \\
\text { writing }\end{array}$ & $\begin{array}{l}\text { I read feedback, work hard to use almost } \\
\text { every suggestion, and seek available } \\
\text { resources to improve my writing }\end{array}$ \\
\hline $\begin{array}{ll}\text { Feedback } & \text { on } \\
\text { linguistic errors } & \end{array}$ & $14.7 \%$ & $13.0 \%$ & $29.9 \%$ & $34.2 \%$ & $8.2 \%$ \\
\hline $\begin{array}{lr}\text { Feedback } & \text { on } \\
\text { structure } & \text { and } \\
\text { organization } & \text { of } \\
\text { essay } & \\
\end{array}$ & $13.0 \%$ & $14.1 \%$ & $33.7 \%$ & $33.2 \%$ & $6.0 \%$ \\
\hline $\begin{array}{l}\text { Feedback on idea, } \\
\text { topics, and content }\end{array}$ & $8.7 \%$ & $14.1 \%$ & $31.5 \%$ & $37.5 \%$ & $8.2 \%$ \\
\hline
\end{tabular}

Given various corrective feedback, it is in line with Table 10, the student interest was mostly on idea, topics, and content. However, most students $(37.5 \%)$ eager to read it and try to use some of suggestions to improve their writing. Feedback on structure and organization of essay is occupied the second position (33.2\%), and the last position feedback on linguistic errors (34.2\%). To apply this, the teacher struggles to give clear feedback since it take more time and attention. Related to the clarity of feedback whether it was clear and easy to understand and even the students never got the CF from their teacher. In respect to this, most students respond that teacher's feedback was somewhat difficult for them (35.9\%), and $33.2 \%$ the students say the CF was moderate. When the students meet this difficulty, face-to-face conference can be carried out to achieve the clarity [16].

Published By

Blue Eyes Intelligence Engineering \& Sciences Publication 
Table 16: The student experiences on clarity of teacher's feedback

\begin{tabular}{|c|c|c|c|c|}
\hline \multicolumn{5}{|c|}{ Frequency of Responses } \\
\hline $\begin{array}{c}\text { I Did } \\
\text { Not Get } \\
\text { Feedback }\end{array}$ & $\begin{array}{c}\text { Very } \\
\text { Difficult }\end{array}$ & $\begin{array}{c}\text { Somewhat } \\
\text { Difficult }\end{array}$ & Moderate & $\begin{array}{c}\text { Very } \\
\text { Clear }\end{array}$ \\
\hline $13.0 \%$ & $12.0 \%$ & $35.9 \%$ & $33.2 \%$ & $6.0 \%$ \\
\hline
\end{tabular}

P. Student Encouragement on Teacher's Corrective Feedback

When asked whether teacher CF encouraged the students, most of them said that the feedback had a little encouragement. Thus, it indicates that the writing teacher needs some positive endeavours in helping English learners acquire clear feedback to improve their academic and professional writing skills. Table 17 shows on how the students encouraged the feedback after he or she received WCF for their teacher.
Table 17: The student encouragement on teacher's feedback

\begin{tabular}{|c|c|c|c|c|}
\hline \multicolumn{5}{|c|}{ Frequency of Responses } \\
\hline I Did & $\begin{array}{c}\text { Not } \\
\text { Not Get } \\
\text { Feedbac } \\
\mathrm{k}\end{array}$ & $\begin{array}{c}\text { A } \\
\text { All }\end{array}$ & $\begin{array}{c}\text { Somewhat } \\
\text { Encouraging }\end{array}$ & $\begin{array}{c}\text { Very } \\
\text { Encouraging }\end{array}$ \\
\hline $11.4 \%$ & $\begin{array}{c}11.4 \\
\%\end{array}$ & $\begin{array}{c}34.2 \\
\%\end{array}$ & $29.3 \%$ & $13.6 \%$ \\
\hline
\end{tabular}

\section{Q. Student Challenging to Use Corrective Feedback}

The students evaluate challenges that inhibit effective use of feedback in four point scales: 0 N/A (not applicable), 1 (no problem), 2 (slightly problematic), 3 (somewhat problematic), and 4 (serious problem). Possible challenges include lack of time, difficult language, irrelevant, inadequate explanations, redundancy, computing skills, access to computers, and program design.

Table 18: The student challenging to use feedback

\begin{tabular}{|l|c|c|c|c|c|}
\hline \multicolumn{1}{|c|}{ Challenging Factors } & \multicolumn{3}{c|}{ Frequency of Responses } \\
\cline { 2 - 5 } & $\begin{array}{c}\text { N/A (Not } \\
\text { Applicable) }\end{array}$ & $\begin{array}{c}\text { No } \\
\text { Problem }\end{array}$ & $\begin{array}{c}\text { A Little } \\
\text { Problematic }\end{array}$ & $\begin{array}{c}\text { Somewhat } \\
\text { Problematic }\end{array}$ & $\begin{array}{c}\text { Seriously } \\
\text { Problematic }\end{array}$ \\
\hline $\begin{array}{l}\text { Lack of time ( I need more time to write and revise } \\
\text { my writing) }\end{array}$ & $4.9 \%$ & $19.6 \%$ & $33.7 \%$ & $32.1 \%$ & $9.8 \%$ \\
\hline $\begin{array}{l}\text { Difficulty of understanding the language (I struggle } \\
\text { to understand what the feedback means.) }\end{array}$ & $3.8 \%$ & $20.1 \%$ & $38.6 \%$ & $29.9 \%$ & $7 . \%$ \\
\hline $\begin{array}{l}\text { Not relevant or inappropriate feedback (The } \\
\text { feedback is wrong. I ignore it) }\end{array}$ & $9.2 \%$ & $14.7 \%$ & $41.8 \%$ & $27.2 \%$ & $7.1 \%$ \\
\hline $\begin{array}{l}\text { Insufficient explanation (Feedback is too broad and } \\
\text { not clear) }\end{array}$ & $9.2 \%$ & $16.8 \%$ & $39.7 \%$ & $26.1 \%$ & $8.2 \%$ \\
\hline Redundant (Same or similar wordings are repeated) & $6.0 \%$ & $17.4 \%$ & $40.2 \%$ & $26.6 \%$ & $9.8 \%$ \\
\hline $\begin{array}{l}\text { Computing skills (I have difficulties to use } \\
\text { computer)-Online Feedback }\end{array}$ & $6.5 \%$ & $16.3 \%$ & $41.8 \%$ & $24.5 \%$ & $10.9 \%$ \\
\hline $\begin{array}{l}\text { Lack of access to the Online feedback site ( I could } \\
\text { not access to the site as often as I wanted) }\end{array}$ & $6.0 \%$ & $20.7 \%$ & $39.1 \%$ & $22.8 \%$ & $11.4 \%$ \\
\hline $\begin{array}{l}\text { Difficulty to use Online feedback program (Online } \\
\text { feedback is too complicated and hard to understand } \\
\text { how to use) }\end{array}$ & $6.0 \%$ & $20.7 \%$ & $35.3 \%$ & $27.7 \%$ & $10.3 \%$ \\
\hline
\end{tabular}

From Table 18 concludes that a little problematic on effectiveness of teacher $\mathrm{CF}$, the highest position was on the irrelevant feedback and computing skill (both 41.8\%), the second position falls into redundancy $(40.2 \%)$, and the last frequency is on lack of access to online feedback site [18]. To sum up, students responded that a little problematic category was not serious one since this can be anticipated by using other types of feedback.

R. Student Perceptions on Writing Assessment
In respect to writing assessment, assessment is commonly used to measure students' writing ability after teaching learning process conducted. Table 19 reveals the students demand on how assessment should be carried out. Table 19 summarizes that EFL learners still expect assessment conducted independently. It is challenging for writing teacher to design the appropriate writing assessment. These findings at least can be used as an additional informational beyond the further discussion between the learners and teacher.

Table 19: The students' need on writing assessment

\begin{tabular}{|c|c|c|c|c|}
\hline \multirow[t]{2}{*}{ Students' Willingness } & \multicolumn{4}{|c|}{ Frequency of Responses } \\
\hline & $\begin{array}{c}\text { I Don't Need At } \\
\text { All }\end{array}$ & $\begin{array}{l}\text { Less Than I } \\
\text { Need }\end{array}$ & Adequate & More Than I Need \\
\hline
\end{tabular}


INTERROGATE INDONESIAN EFL LEARNERS' NEEDS ON ACADEMIC WRITING INSTRUCTION

\begin{tabular}{|l|c|c|c|c|}
\hline I do the writing test by myself. & $7.1 \%$ & $33.7 \%$ & $37.0 \%$ & $22.3 \%$ \\
\hline $\begin{array}{l}\text { I need friends' assistance during the writing } \\
\text { test. }\end{array}$ & $9.8 \%$ & $40.2 \%$ & 34.85 & $15.2 \%$ \\
\hline $\begin{array}{l}\text { I need lecturer's assistance during the writing } \\
\text { test. }\end{array}$ & 9.25 & $32.6 \%$ & $42.4 \%$ & $15.8 \%$ \\
\hline $\begin{array}{l}\text { I need assessment integrated in process writing } \\
\text { instruction. }\end{array}$ & $6.5 \%$ & $28.3 \%$ & $46.2 \%$ & $19.0 \%$ \\
\hline
\end{tabular}

\section{DISCUSSION}

It is obvious that the EFL undergraduate students need urgently for English in academic writing instruction. A different background knowledge, demands of instruction, and language assessment are some of the conditions for providing curriculum. Some beneficial findings of the needs analysis survey captured the researcher's attention. In regard to writing instruction, writing teacher pay particular attention on designing the curriculum since students' interest are divergent, including teaching writing (which cover writing process), written feedback, and assessment. In respect to students' background, it is important to understand students' background due to learning is social activity in which interaction between teacher and students, and students with their classmate is built to create good atmosphere in learning. Thus, "it is important to both recognize and affirm L2 students' L1 background and understand that their writing does not directly reflect their exotic culture but is significantly shaped by educational practices, local politics and ideologies, as well as transactional discourses in the age of globalization [19].

The demands of the texts the students need in particular area are essential that 'before developing a genre-based program, the teacher or institution would need to conduct an analysis of the teaching/learning context [20]. Thus, this analysis served the improvement of the students' learning motivation as [21] state that 'much research has indeed demonstrated that individuals offered choice will show more enjoyment of, better performance on, and greater persistence at a variety of activities. Indeed, writing take more time and energy. Although the findings reveals that the students wants only two credits, it is required to conduct more discussion with the writing teachers and the students since writing process takes time and attention [22]. To do this, off course, two credits for academic writing course is not sufficient. However, academic writing teacher is required for determine better course credit or perhaps another session out of class.

In response to the question about writing process (planning, drafting, revising), most students answered they sometime carried out procedures. The writing process into writing course was seemingly absent from foreign language curriculum and classrooms [21]. It is required more attention in order to better writing, 'academic writing teachers should examine their students' written texts diachronically through the lens of varying cultural norms and patterns in terms of both writing processes and written products [23]. However, the researcher proposes that academic writing tell the students that writing process and written product as integral part to create better text.

The goal of writing allow the writer to take into account proactively the reader's expectations and reactions. Although there have been many studies on writing process, in [14] argues that there is not any comprehensive idea of how learners go about a writing task or how they learn to write. Nevertheless, the alternative to teach writing is genre-based approach (GBA) which covers two main teaching-learning cycles: Writing with the class and Writing independently. To apply this, at least, writing teacher determines how much the students need on the writing process (planningdrafting-revising) embedded in GBA. In GBA, planning can be strengthened as most students need.

Written corrective feedback (WCF) has played important role to improving accuracy. To make it effective, it is important to consider students' need in term of the students' preference on the type of WCF, the students' responses on corrective feedback, the clarity of teacher's feedback, the students' encouragement on teacher's corrective feedback, and students' challenging to use corrective feedback as findings of this study. In addition, it is also important that the students know and understand what he or she will do with WCF since 'feedback that the student does not understand cannot help him or her to improve [15]. Thus, academic writing teacher should consistently provide students with clear WCF on their attempts in evaluating their work [20]-[23].

In respect to writing assessment, assessing writing needs to consider student development. The findings of this study reveals that teacher mediation important for them. To do this, academic writing teacher should apply dynamic assessment in which leaners and academic writing teacher can interact during assessment. Consequently, both teacher and mediation can assist students to promote their development.

\section{CONCLUSION}

Although this needs analysis showed beneficial, there are few limitations to be pointed out. First, size of sample is relatively small. It would be worth exploring a larger size of the sample or other institutional setting to strengthen what students' needs on academic writing instruction. Second, single technique of data collection was utilized. Future studies could use multiple techniques such as interview, test, observation, meeting and so on. Lastly, this study did not involve the academic writing teacher whether the frequency of the data in any way

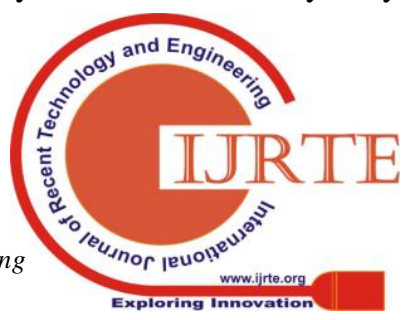


affected how the academic writing instruction to be. Therefore, future studies could include the teachers by conducting text-based interviews. Such studies would shed light on the extent to which interactional features in academic writing instruction like.

\section{REFERENCES}

1. N. C. Noemi, "From needs analysis to designing academic writing materials for diploma students of MARA University of Technology (UiTM), Malaysia," International Journal of Language Education and Culture Review, 1(2), 2015, pp. 76-86.

2. M. L. Gea-Valor, J. Rey-Rocha, and A. I. Moreno, "Publishing research in the international context: An analysis of Spanish scholars' academic writing needs in the social sciences," English for Specific Purposes, 36, 2014, pp. 47-59.

3. P. Knapp, and M. Watkins, Genre, Text, Grammar: Technologies for Teaching and Assessing Writing. Sydney: University of New South Wales Press, 2005.

4. M. Alotaibi, and A. Mahmood, "Improved gait recognition based on specialized deep convolutional neural network," Computer Vision and Image Understanding, 164, 2017, pp. 103-110.

5. H. P. Widodo, and A. Novawan, "Implementing Wiki and Blog mediated writing task in an EFL context," in ICT and ELT: Research and Practices in South East Asia, M. K. Kabilan, W. K. Too and H. P. Widodo, Eds. Pulau Pinang: Universiti Sains Malaysia, 2012, pp. 1-16.

6. I. Harjanto, "Teaching EFL academic writing through ISearch," Language Education in Asia, 5(1), 2014, pp. 151 159.

7. R. Fernandez, J. K. Peyton, and K. Schaetzel, "A survey of writing instruction in adult ESL programs: Are teaching practices meeting adult learner needs?" Journal of Research and Practice for Adult Literacy, Secondary, and Basic Education, 6(2), 2017, pp. 5-20.

8. P. Farrokh, and A. Rahmani, "Dynamic assessment of writing ability in transcendence tasks based on Vygotskian perspective," Asian-Pacific Journal of Second and Foreign Language Education, 2(1), 2017, pp. 1-23.

9. L. Xiaoxiao, and L. Yan, "A case study of dynamic assessment in EFL process writing," Chinese Journal of Applied Linguistics, 33(1), 2010, pp. 24-40.

10. M. E. Poehner, Dynamic Assessment: A Vygotskian Approach to Understanding and Promoting L2 Development. Berlin: Springer Science and Business Media, 2008.

11. W. C. Resing, W. M. Steijn, I. Xenidou-Dervou, C. E. Stevenson, and J. G. Elliott, "Computerized dynamic testing: A study of the potential of an approach using sensor technology," Journal of Cognitive Education and Psychology, 10(2), 2011, pp. 178-194.

12. H. P. Widodo, "Language policy in practice: Reframing the English language curriculum in the Indonesian secondary education sector," in English Language Education Policy in Asia, R. Kirkpatrick, Ed. Cham: Springer, 2016, pp. 127-151.

13. K. Hyland, "Genre-based pedagogies: A social response to process," Journal of Second Language Writing, 12(1), 2003, pp. 17-29.

14. H. P. Widodo, "Approaches to needs analysis in ESP curriculum development," European Journal of Applied Linguistics and TEFL, 6(1), 2017, pp. 127-146.

15. J. Choi, The Impact of Automated Essay Scoring (AES) for Improving English Language Learner's Essay Writing. Charlottesville: University of Virginia, 2010.

16. D. R. Ferris. Response to Student Writing: Implications for Second Language Students. Abigdon: Routledge, 2003.
17. W. A. Renandya, and H. P. Widodo, English Language Teaching Today: Linking Theory and Practice. Berlin: Springer, 2016.

18. J. Foley, "Developing academic writing in a business oriented university," Indonesian Journal of Applied Linguistics, 2(2), 2013, pp. 168-186.

19. R. F. Craig, Soil Mechanics. Berlin: Springer, 2013.

20. W. Zhang, and Y. L. Cheung, "Researching innovations in English language writing instruction: A state-of-the-art review," Journal of Language Teaching and Research, 9(1), 2018, pp. 80-89.

21. H. Widodo, "Designing a genre-based lesson plan for an academic writing course," English Teaching, 5(3), 2006, pp. 173-199.

22. A. Endut, S. H. Y. S. Abdullah, N. H. M. Hanapi, S. H. A. Hamid, F. Lananan, M. K. A. Kamarudin, R. Umar, H. Juahir, and H. Khatoon, "Optimization of biodiesel production by solid acid catalyst derived from coconut shell via response surface methodology," International Biodeterioration and Biodegradation, 124, 2017, pp. 250257.

23. M. Ni, M. K. Leung, D. Y. Leung, and K. Sumathy, "A review and recent developments in photocatalytic watersplitting using $\mathrm{TiO}_{2}$ for hydrogen production," Renewable and Sustainable Energy Reviews, 11(3), 2007, pp. 401425 . 